\title{
KOHERENSIESIN, SELFDOELTREFFENDHEID, LOKUS VAN BEHEER EN UITBRANDING BY MAATSKAPLIKE WERKERS
}

\author{
S. ROTHMANN \\ H. MALAN \\ WorkWell: Navorsingseenheid vir Mense, Beleid en Prestasie, \\ Fakulteit Ekonomiese en Bestuurswetenskappe \\ PU vir $\mathrm{CHO}$
}

\begin{abstract}
OPSOMMING
Die doelstelling van hierdie artikel is om te rapporteer oor verbande tussen maatskaplike werkers se koherensiesin, selfdoeltreffendheid en lokus van beheer enersyds en uitbranding andersyds, en die mate waarin hierdie veranderlikes hul uitbranding kan voorspel. 'n Opnameontwerp is gebruik. Die ondersoekgroep het bestaan uit 107 maatskaplike werkers. Vier vraelyste is gebruik, naamlik die Lewensoriëntasievraelys, die Algemene Selfdoeltreffendheidsvraelys, die Werk-Lokus-van-Beheer-vraelys en die Maslach-Uitbrandingsvraelys. Die resultate van die empiriese ondersoek dui daarop dat daar prakties betekenisvolle verbande bestaan tussen maatskaplike werkers se koherensiesin, selfdoeltreffendheid en lokus van beheer enersyds en hul vlak van uitbranding andersyds.
\end{abstract}

\begin{abstract}
The objective of this article is to report on the relationships between social workers' sense of coherence, self-efficacy and locus of control on the one hand and burnout on the other hand, and the extent to which these variables can predict their burnout. A survey design was used. The study population consisted of 107 social workers. Four questionnaires were used in the research, namely the Orientation to Life Questionnaire, the General Perceived Self-Efficacy Scale, the Work of Locus of Control Scale and the Maslach Burnout Inventory. The results showed that practically significant relationships exist between social workers' sense of coherence, self-efficacy and locus of control on the one hand and burnout on the other hand.
\end{abstract}

\section{SYNOPSIS}

The current behavioural science field of study is characterised by an increased interest in the relationship between the physical and psychological aspects of human functioning. Furthermore, the responsibility of the modern organisation regarding the total health of the employee is also stressed. This is also the case for the occupation of social work. A general viewpoint is that the provision of social work services is stressful and it could lead to burnout. According to Maslach and Jackson (1981a), burnout emerges in "helping" professions because of emotional over-stimulation and the resulting inability to make contact with clients. Constant exposure to pathology, demands to adapt to economic, socio-political and technological change, inapplicable administrative and organisational structures, a lack of resources, and the enormity of needs are frequently given as reasons for stress and burnout.

Based on the definitions of Freudenberger (1980), Maslach (1982b), Meier (1983) and Harrison (1983) burnout can be defined as a stress reaction experienced by individuals when the expected results of their services do not realise. Maslach define burnout as follows: "Burnout is a syndrome of emotional exhaustion and cynicism..." (Maslach \& Jackson, 1981b, p. 1). Personal, work-specific and societal factors may contribute to burnout.

Recent research increasingly focuses on dispositional factors that could lead to burnout. A disposition is defined as "... any hypothesised organisation of mental and physical aspects of a person that is expressed as a stable, consistent tendency to exhibit particular patterns of behaviour in a broad range of circumstances" (Reber, 1995, p. 218). In this article the dispositional causes of burnout are researched from a fortigenic paradigm (Strümpfer, 1995). The fortigenic paradigm focuses on the origins of strengths within people. This paradigm differs from the pathogenic paradigm, which focuses on the origins of illness. This article focuses on three constructs that are related to the fortigenic paradigm, namely sense of coherence (Antonovsky, 1991), self-efficacy (Bandura, 1997) and locus of control (Rotter, 1966).

No research regarding the relationship between sense of coherence, self-efficacy and locus of control has been undertaken with social

Versoeke vir afskrifte moet gerig word aan: S Rothmann, WorkWell:

Navorsingseenheid vir Mense, Beleid en Prestasie, Fakulteit Ekonomiese en

Bestuurswetenskappe, PU vir CHO, Privaatsak X6001, Potchefstroom, 2520 workers in welfare organisations. If a significant relationship between these variables and burnout is found, it could be of value to welfare organisations, especially regarding the prevention of burnout and the improvement of the quality of life of social workers.

The objective of the research was to determine whether relationships exist between social workers' sense of coherence, selfefficacy and locus of control on the one hand and burnout on the other hand, and to determine whether these variables can predict their burnout. A survey design was used. The study population consisted of 107 social workers. Four questionnaires were used in the research, namely the Maslach Burnout Inventory, the Orientation to Life Questionnaire, the General Perceived SelfEfficacy Scale and the Work Locus of Control Scale. The results showed that there is a correlation between a social worker's extent of coherence, self-efficacy and locus of control on the one hand and burnout on the other hand. Emotional exhaustion was best predicted by sense of coherence and marital status. Sense of coherence, locus of control and marital status best predict cynicism. Generalised self-efficacy, work status and gender best predicted personal efficacy.

Die hedendaagse gedragswetenskaplike studieveld word onder andere gekenmerk deur die verhoogde vlak van belangstelling in psigologiese gesondheid van individue (kyk Ryan \& Deci, 2000; Seligman \& Csikszentmihalyi, 2000). Verder word die verantwoordelikheid van die moderne organisasie ten opsigte van die totale gesondheid van die werknemer al hoe meer beklemtoon (Schaufeli \& Enzmann, 1998). Dieselfde geld ook vir die beroep van maatskaplike werk (Jayaratne, Vinokur-Kaplan \& Chess, 1995).

'n Algemene uitgangspunt is dat die lewering van maatskaplikewerk-diens baie stresvol is en gevolglik kan lei tot uitbranding, wat weer verantwoordelik is vir die hoë personeelomset van maatskaplike werkers in Suid-Afrika (Ross \& Fridjhon, 1995). Volgens Maslach en Jackson (1981a) ontstaan uitbranding by die hulpverlenende beroepe as gevolg van emosionele oorstimulering met 'n gevolglike onvermoë om kontak te maak met kliënte. Die konstante blootstelling aan patologie, die eise om aan te pas by ekonomiese, sosio-politieke en tegnologiese verandering, onvanpaste administratiewe en organisatoriese strukture, tekort aan hulpbronne om effektief die kliënt se 
behoeftes te kan hanteer en die enormiteit van behoeftes, word gereeld as die oorsaak van stres en uitbranding aangevoer (Ross \& Fridjhon, 1995).

Uitbranding kan dus die lewering van maatskaplike-werk-diens beduidend beinvloed. Daar is ' $n$ toenemende besef dat voorkoming goedkoper is as genesing en dat 'n gesonde lewenstyl ' $n$ belangrike bydrae lewer ter voorkoming van stresverwante siektes soos hartsiektes, hoë bloeddruk en chroniese moegheidsindroom (Schaufeli \& Enzmann, 1998). Die menshulpbron is die belangrikste bate in 'n diensorganisasie. Hoe meer gedragwetenskaplikes kan verstaan aangaande uitbranding, hoe 'n groter bydrae kan hulle lewer ter voorkoming daarvan en verhoging van die mens se lewenskwaliteit en realisering van potensiaal.

Uitbranding kan beskryf word, met inagneming van die definisies van Freudenberger (1980), Maslach (1982b), Meier (1983), Harrison (1983), as 'n stresreaksie wat individue in mensgerigte professies kan ervaar wanneer die verwagte resultate van hulle dienste nie realiseer nie. Schaufeli en Enzmann (1998, p. 36) definieer uitbranding soos volg: "Burnout is a persistent, negative, work-related state of mind in 'normal' individuals that is primarily characterized by exhaustion, which is accompanied by distress, a sense of reduced effectiveness, decreased motivation, and the development of dysfunctional attitudes and behaviors at work."

In resente navorsing word daar dikwels gefokus op die faktore binne individue (disposisionele faktore) wat lei tot uitbranding (Schaufeli \& Enzmann, 1998). 'n Disposisie word gedefinieer as “... any hypothesized organization of mental and physical aspects of a person that is expressed as a stable, consistent tendency to exhibit particular patterns of behaviour in a broad range of circumstances" (Reber, 1995, p. 218). House, Shane en Herold (1996) beskryf disposisies as psigologiese eerder as fisieke dimensies, naamlik persoonlikheidskenmerke, behoeftes, houdings, voorkeure en motiewe wat eindig in ' $n$ geneigdheid om op 'n voorafbepaalde wyse op 'n sekere situasie te reageer.

In die onderhawige navorsing word die disposisionele oorsake van uitbranding vanuit 'n fortigene paradigma (Strümpfer, 1995) nagevors. Die fortigene paradigma fokus op die oorsprong van kragte binne mense. Hierdie paradigma verskil van die tradisionele patogene benadering tot gesondheid waar daar gefokus is op die oorsprong van die siekte. In die huidige navorsing word daar gefokus op drie konstrukte wat verwant is aan die fortigene paradigma, naamlik koherensiesin (Antonovsky, 1991), selfdoeltreffendheid (Bandura, 1997) en lokus van beheer (Rotter, 1966). Antonovsky (1991) beskou hierdie konstrukte as relatief stabiele, disposisionele oriëntasies.

Geen navorsing betreffende die verband tussen koherensiesin, selfdoeltreffendheid en lokus van beheer en uitbranding ten opsigte van geregistreerde welsynsorganisasies is opgespoor nie. As daar egter betekenisvolle negatiewe verbande tussen hierdie veranderlikes en uitbranding bestaan, kan dit tot groot nut vir die organisasie wees, veral ten opsigte van voorkoming van uitbranding en die verbetering van werknemers se kwaliteit van werkslewe. Vir die doel is die navorsing wat in hierdie artikel rapporteer word, onderneem om die verband tussen koherensiesin, selfdoeltreffendheid, lokus van beheer en uitbranding te bepaal en vas te stel of hierdie veranderlikes maatskaplike werkers se uitbranding kan voorspel.

\section{Uitbranding}

Uitbranding word deur Freudenberger (1974) beskou as 'n staat van uitputting wat toegeskryf kan word aan oormatige eise op die mens se energiebronne. Dié uitputting word deur hom beskryf ooreenkomstig simptome van moegheid, neerslagtigheid, apatie, skuldgevoelens en gevoelens van hulpeloosheid. Maslach definieer uitbranding soos volg:
"Burnout is a syndrome of emotional exhaustion and cynicism..." (Maslach \& Jackson, 1981b, p.1). Volgens Schaufeli en Enzmann (1998) is uitbranding 'n volgehoue, negatiewe, werksverwante toestand by normale individue, wat primêr gekenmerk word deur uitputting en wat gepaardgaan met spanning, ' $n$ sin van verlaagde effektiwiteit, 'n afname in motivering en die ontwikkeling van disfunksionele houdings en gedrag by die werk.

Stres moet nie met uitbranding verwar word nie. Volgens Schaufeli en Enzmann (1998) kan uitbranding beskou word as 'n spesifieke tipe van verlengde werkstres. Individue ervaar werkstres as die eise van hul werksplek hul aanpassingsresponse oorskry. Uitbranding is die finale stap in 'n progressie van onsuksesvolle pogings om met 'n verskeidenheid van strestoestande te cope. Uitbranding moet ook van depressie onderskei word (Schaufeli \& Enzmann, 1998). Uitbranding vind plaas in 'n konteks van woede eerder as skuld. 'n Depressiewe persoon se simptome veralgemeen oor alle situasies, terwyl uitbranding werksverwant is.

Uitbranding word deur Schaufeli en Enzmann (1998) gekonseptualiseer as 'n sindroom wat uit drie interverwante dog konseptueel-onderskeidende kenmerke, naamlik uitputting, sinisme en lae persoonlike doeltreffendheid bestaan.

- Uitputting verwys na 'n vermindering in die emosionele bronne van 'n individu.

- Depersonalisasie verwys na 'n toename in negatiewe en siniese houdings teenoor kollegas, kliënte en pasiënte.

- Lae persoonlike bereiking verwys na gevoelens van onvermoë kliënte se behoeftes te bevredig en essensiële elemente van werksprestasie bevredigend na te kom.

Die simptome van 'n werknemer wat aan uitbranding lei, kan soos volg saamgevat word (Schaufeli \& Enzmann, 1998):

- Affektiewe simptome. Werknemers wat uitgebrand is, toon 'n depressiewe luim. Die werknemer se emosionele bronne is uitgeput omdat te veel energie vir te lank gebruik is. Sy of haar emosionele kontrole verminder, wat lei tot ongedefinieerde vrese, angs en spanning. Werknemers wat uitgebrand is, is geïrriteerd, hipersensitief, maar toon ook by tye 'n gebrek aan emosies. Woede-uitbarstings kom ook soms voor.

- Kognitiewe simptome. Werknemers wat uitgebrand is voel hulpeloos, hopeloos en magteloos. Die betekenis van werk gaan verlore en dus ervaar hulle mislukking. Sodanige persone vind dit ook moeilik om te konsentreer, is vergeetagtig en maak allerlei kleiner foute. Hulle raak rigied in hul denke en persoonlike en emosionele aangeleenthede word geintellektualiseer. Werknemers wat uitgebrand is vind dit moeilik om besluite te neem en ontwyk realiteit deur te dagdroom en te fantaseer. Op interpersoonlike vlak is hulle geneig om minder by kliënte betrokke te wees, wat sigbaar is in negatiwiteit, pessimisme, vyandigheid, agterdog, ongevoeligheid en stereotipering.

- Fisieke simptome. Drie kategorieë van simptome word gewoonlik in uitgebrande individue waargeneem. Eerstens word allerlei nie-definitiewe fisieke stres-simptome waargeneem, byvoorbeeld hoofpyne, naarheid, duiseligheid, rusteloosheid, spierpyne, hiperventilasie, seksuele probleme, slaapversteurings, skielike gewigsverlies of -toename en chroniese moegheid. Tweedens word psigosomatiese simptome soos maagsere, gastro-intestinale afwykings, koronêre hartsiektes, voortdurende verkoue en griep en geneigdheid tot virusinfeksies waargeneem. Derdens word 'n aantal fisiologiese reaksies waargeneem, byvoorbeeld verhoogde harttempo en asemhalingstempo, hipertensie en hoë vlakke van serum cholesterol.

- Gedragsimptome. Die werknemer wat uitgebrand is, is geneig om hiperaktief te wees maar weet nie wat om te doen of waarheen om te gaan nie. Hy of sy tree impulsief op sonder om alternatiewe moontlikhede te ondersoek. Aan die ander kant is die individu onseker, besluiteloos en geneig om 
uit te stel. Die gebruik van stimulante, soos koffie en tabak, verhoog terwyl die individu dikwels ook meer alkohol, barbiturate en/of medisyne gebruik. Die individu is geneig om te veel of te min te eet en is ook geneig tot ongelukke. Op interpersoonlike vlak is die individu geneig om aggressief te wees, om hom- of haarself te isoleer en te onttrek. Op organisasievlak word uitbranding gekenmerk deur laer effektiwiteit, swak prestasie en lae produktiwiteit.

- Motiveringsimptome. Die uitgebrande individu se intrinsieke motivering verdwyn: entoesiasme, belangstelling en idealisme gaan verlore. Die individu is teleurgesteld, ontnugter en geneig om te onttrek. Op interpersoonlike vlak kom die motiveringskrisis na vore in minder belangstelling in kliënte, onverskilligheid en ontmoediging. Die individu is ongemotiveerd om te werk en sy of haar inisiatief is gedemp.

Volgens Maslach kom die verskynsel van uitbranding veral na vore in die "mens-intensiewe" professies weens die dikwels dubbelsinnige en frustrerende probleme in hulpverlening wat lei tot voortdurende stres (Maslach \& Jackson, 1981b). Dié stres lei tot uitputting en ' $n$ verlies aan psigologiese reserwes. Die tekorte aan reserwes lei daartoe dat kliënte op 'n siniese negatiewe wyse beskou word en vorm dit die tweede been van die sindroom. In die derde plek ontstaan daar ook 'n negatiewe evaluering van die self en eie vermoëns.

Individue se persoonlikheidsfaktore kan daartoe lei dat hulle uitbranding ontwikkel (Venter, 1989). Schaufeli en Enzmann (1998) bevestig dat 'n werknemer se persoonlikheidseienskappe verwant kan wees aan uitbranding. 'n Geharde persoonlikheid, 'n konfronterende coping-styl, selfagting en ekstroversie is negatief verwant aan uitbranding, terwyl eksterne kontroleoriëntasies, A-tipe gedrag en neurotisisme, positief aan uitbranding verwant is. Die neiging om omstandighede of gebeure as stresvol waar te neem, hang van die disposisionele eienskappe van 'n persoon af. Vir die doeleindes van die navorsing word daar gefokus op die werknemer se koherensiesin, selfdoeltreffendheid en lokus van beheer en die moontlike verbande hiervan met uitbranding.

Koherensiesin, selfdoeltreffendheid en lokus van beheer Antonovsky (1987a) definieer koherensiesin soos volg: "The sense of coherence is a global orientation that expresses the extent to which one has a pervasive, enduring though dynamic feeling of confidence that the stimuli deriving from one's internal and external environments in the course of living are structured, predictable and explicable; the resources are available to one to meet the demands posed by these stimuli; and these demands are challenges worthy of investment and engagement". Dié definisie sluit drie dimensies in wat die konsep koherensiesin verteenwoordig, naamlik verstaanbaarheid, hanteerbaarheid en betekenisvolheid. Verstaanbaarheid, verwys na die mate waarin individue waarneem dat stimuli waardeur hulle gekonfronteer word, kognitief sin maak. Hanteerbaarheid verwys na die mate waarin die individue gebeure as hanteerbaar ervaar, selfs as nuwe uitdagings beskou. Betekenisvolheid op die mate waarin ' $n$ mens voel dat die lewe emosioneel, eerder as kognitief, ook sin maak (Antonovsky, 1987a).

Bowman (1996) het in sy studies bevind dat koherensiesin belangrik is in die hantering van stres ten einde fisieke en psigologiese gesondheid te verseker. Gilbar (1998) het bevind dat maatskaplike werkers met 'n sterk koherensiesin minder uitbranding beleef as dié met ' $n$ swak koherensiesin. Dit is bewys dat die hanteerbaarheidskomponent in koherensiesin ' $n$ voorspeller van emosionele moegheid is. Feldt (1997) het bevind dat daar 'n sterk negatiewe korrelasie tussen koherensiesin en uitbranding bestaan. Basson en Rothmann (2002) het bevind dat individue met 'n sterk koherensiesin (vergeleke met diegene met 'n swak koherensiesin) minder uitbranding ervaar. Hoe sterker die koherensiesin, hoe groter is die neiging om die aard van die stressor te identifiseer waarmee hulle gekonfronteer word en om gepaste hulpbronne vir die gegewe situasie te kies.
In studies met universiteitspersoneel en universiteitstudente het Wissing, de Waal en de Beer (1992) korrelasies van -0,50 tot 0,64 tussen Pines, Aronson en Kafry (1981) se Uitbrandingskaal en die drie subskale van Antonovsky (1987a) se Lewensoriëntasievraelys gevind. Hierdie vier skale het gesamentlik een faktor gedefinieer, met ladings tussen 0,79 en 0,86 (hoewel die Uitbrandingskaal ' $n$ negatiewe belading op die faktor getoon het). Op grond van hierdie bevinding het Wissing et al. (1992) aangedui dat 'n dimensie met salutogene en patogene pole moontlik gemeet is, met koherensiesin op die een pool en uitbranding op die ander pool.

Bandura en Wood (1989) en Judge, Locke en Durham (1997) definieer selfdoeltreffendheid as die geloof of vertroue wat mense het om deur die middel van eie motivering, kognitiewe hulpbronne en spesifieke aksies 'n situasionele eis te kan hanteer. Gist (1987) definieer selfdoeltreffendheid as die geloof wat ' $n$ persoon het dat die korrekte gedrag geopenbaar kan word om 'n spesifieke taak suksesvol af te handel.

Schaubroeck en Merrit (1997) bevind in hulle navorsing dat wanneer individue vertroue in hulle eie vermoëns het, hulle meer beheer oor die situasie het en sal die hoeveelheid stres wat hulle ervaar, verminder. Persone met 'n hoë selfdoeltreffendheid benader stresvolle situasies met die geloof dat hy of sy die situasie sal kan hanteer en ervaar, dus nie soveel stres nie. Persone met 'n lae selfdoeltreffendheid sal meer stres ervaar, aangesien hulle minder vertroue in hul eie vermoëns het. Dié persone verwag dat hulle gedrag tot mislukking sal lei. Die hoeveelheid stres en angs wat 'n persoon beleef, lei tot uitbranding.

Rotter (1966) definieer lokus van beheer as die mate waarin mense ' $n$ interne of eksterne beheerpunt in hulle lewens sien. Persone wat oor ' $n$ interne lokus van beheer beskik, sien die uitvloeisel van hulle gedrag as die gevolg van hulle eie gedrag, vermoëns of persoonlike eienskappe en is gevolglik van mening dat hulle self ' $n$ groot mate van beheer kan uitoefen oor wat met hulle gebeur. Persone wat oor 'n eksterne lokus van beheer beskik, glo dat die uitvloeisel van hul gedrag die resultaat is van eksterne invloede soos geluk, toeval, die noodlot of die invloed van ander mense.

Jones en Page (1986) het bevind dat persone met 'n interne lokus van beheer minder angs ervaar. Tubbs (1994) toon in sy navorsing dat daar sterk bewyse is dat persone met ' $n$ interne lokus van beheer druk beter kan hanteer. Dié persone het 'n duideliker sin en begrip van hulle doelwitte en waardes en gebruik geleenthede om die doelwitte te verwesenlik. Daarteenoor is persone met 'n eksterne lokus van beheer onseker oor hulle vermoë om met daaglikse lewenseise te cope. Tubbs (1994) bevind verder dat persone met 'n eksterne lokus van beheer moeilik druk en onsekerheid kan hanteer. Rahim (1996) bevestig in sy studies dat persone met 'n eksterne lokus van beheer nie die druk, onsekerheid en uitdagings van 'n veeleisende werksomgewing kan hanteer nie. 'n Persoon met interne lokus van beheer sal dus as gevolg van die gevoel van beheer oor die omgewing in staat wees om eise vanuit die omgewing beter te hanteer as 'n persoon met 'n eksterne lokus van beheer en dus ook effektiewer cope binne die omgewing.

Volgens Antonovksy (1979) kan die konstruk koherensiesin ook in verband gebring word met lokus van beheer. Kalimo en Vuori (1990) vind dat koherensiesin ook sommige van die elemente wat in die konstruk lokus van beheer gevind word, insluit. Koherensiesin en lokus van beheer lei albei tot die antisipering van welstandsbevorderingsoriëntasies. Volgens Seeman en Seeman (1983) ontwikkel mense welstandsbevorderingsoriëntasie deur die teenwoordigheid van dié twee konstrukte.

Judge, Locke, Durham en Kluger (1998) wys daarop dat daar 'n ooreenkoms tussen lokus van beheer en selfdoeltreffendheid 
bestaan. Selfdoeltreffendheid verwys na die geloof wat 'n persoon het in sy of haar vermoë om 'n taak uit te voer, waar lokus van beheer verwys na die geloof wat 'n persoon het dat sy of haar gedrag die verlangde resultaat sal oplewer (Rotter, 1966). Beide die konstrukte lokus van beheer en selfdoeltreffendheid beklemtoon volgens Bandura (1997) die geloof wat 'n persoon het in eie vermoëns om beheer oor ' $n$ spesifieke situasie in sy lewe uit te oefen. Volgens Sherer en Maddux (1982) korreleer 'n hoë mate van selfdoeltreffendheid met 'n interne lokus van beheer. In teenstelling hiermee sal persone met 'n eksterne lokus van beheer aan hul selfdoeltreffendheid twyfel (Lefcourt, 1982; Rotter, 1966).

Op grond van bogenoemde uiteensetting word die hipotese gestel dat uitbranding by maatskaplike werkers negatief verwant sal wees aan koherensiesin, selfdoeltreffendheid en 'n interne lokus van beheer. 'n Maatskaplike werker met 'n sterk koherensiesin sal minder geneig wees om uitbranding te ervaar omdat hy of sy in staat sal wees om eise te verstaan (m.a.w. dit as duidelik, ordelik en voorspelbaar te beskou), en dit as hanteerbaar en betekenisvol te beskou (wat hom of haar sal motiveer om dit konstruktief te hanteer). 'n Hoë vlak van selfdoeltreffendheid sal daartoe bydra dat ' $n$ maatskaplike werker minder uitbranding ervaar as gevolg van die geloof dat hy of sy die korrekte gedrag kan openbaar om die eise van die omgewing te hanteer. ' $n$ Maatskaplike werker met ' $n$ interne lokus van beheer sal minder geneig wees om uitbranding te ervaar as gevolg van 'n geloof dat hy of sy beheer kan uitoefen oor die uitkomste van eie gedrag, wat sal bydra tot motivering om eise te hanteer.

\section{METODE}

\section{Navorsingsontwerp}

'n Opname-ontwerp is in die empiriese ondersoek gebruik (Huysamen, 1993). Elke individu is op dieselfde tydstip volgens al vier konstrukte gemeet deur die verskillende meetinstrumente af te lê. Daarna is die verband tussen die verskillende metings bepaal.

\section{Ondersoekgroep}

Die teikenpopulasie van die ondersoek is maatskaplike werkers van geregistreerde welsynsorganisasies $(N=120)$. Die organisasies wat by die ondersoek betrek is, is nie-staatsorganisasies en lewer primêr kinder- en gesinsorgdienste. 'n Beskikbaarheidsteekproef is gebruik om die ondersoekgroep saam te stel. Daar is 107 vraelyste terug ontvang, wat die responskoers op $89 \%$ te staan bring. Die groep se ouderdomme wissel tussen 22 en 43 jaar, en 33,64\% het 'n dienstydperk van tussen 5 en 9 jaar. Die kenmerke van die ondersoekgroep word in Tabel 1 gerapporteer.

TABeL 1

KENMERKE VAN DIE ONDERSOEKGROEP

\begin{tabular}{llc}
\hline Veranderlike & & $\boldsymbol{n}$ \\
\hline Geslag & Manlik & 4 \\
& Vroulik & 103 \\
Taal & Afrikaans & 97 \\
& Engels & 1 \\
& Tswana & 5 \\
& Ander & 4 \\
Huwelikstatus & Ongetroud & 24 \\
& Getroud & 78 \\
& Geskei & 3
\end{tabular}

\section{Meetinstrumente}

Die Maslach Burnout Inventory - General Survey (MBI-GS) (Maslach, Jackson \& Leiter, 1996) is gebruik om die respondente se verhouding tot hulle werk op 'n kontinuum van betrokkenheid tot uitbranding te meet. Die MBI-GS bestaan uit drie subskale, naamlik Uitputting, Sinisme en Professionele Doeltreffendheid. Die drie subskale bied gesamentlik 'n driedimensionele perspektief op uitbranding. Die MBI-GS bestaan uit 16 items. Maslach et al. (1996) vind Cronbach alfakoëffisiënte vir verskillende studies wat varieer van 0,87 tot 0,89 vir Uitputting, 0,73 tot 0,84 vir Sinisme en 0,76 tot 0,84 vir Professionele Doeltreffendheid. Maslach en Jackson (1981a, 1986) en Lahoz en Mazon (1989) het Cronbach alfakoëffisiënte wat varieer van 0,71 tot 0,90 vir die drie subskale van die MBI, gerapporteer. Toets-hertoetsbetroubaarheid van die MBI varieer van 0,60 tot 0,82 en 0,54 tot 0,60 (na ' $n$ jaar). Eksterne geldigheid van die MBI is afkomstig van die analisering van die konvergensie van gelyke waardes, werksdimensies geassosieer met uitbranding en stresuitkomste (Maslach \& Jackson, 1984b).

Die Lewensorientasievraelys (LOV) (Antonovsky, 1987a) is gebruik om koherensiesin te bepaal. Die LOV bestaan uit 29 items. Volgens Antonovsky (1993) wissel die alfakoëffisiënte van die LOV van 0,82 tot 0,95 . Antonovsky (1987a) rapporteer 'n hoë mate van interne konsekwentheid en betroubaarheid deur betroubaarheidskoëffisiënte wat wissel tussen 0,84 en 0,93 aan te haal. Antonovsky (1987a) haal ook Rumbaut, Anderson en Kaplan (1983) aan wat in verdere navorsing met 'n steekproef van 336 persone 'n betroubaarheidskoëffisiënt van 0,88 verkry het. Die toets-hertoetsbetroubaarheid van die LOV is 0,54 (na twee jaar). Die skaal beskik oor hoë inhoudsgeldigheid asook konstrukgeldigheid. Antonovsky (1993) kom tot die gevolgtrekking dat die LOV 'n betroubare instrument vir die meting van koherensiesin is. Pretorius en Rothmann (2001) se navorsing toon 'n alfakoëffisiënt van 0,93 vir die LOV, terwyl Naude en Rothmann (2000) 'n waarde van 0,88 gevind het. Volgens Antonovsky (1987a) is positiewe bewyse t.o.v. kriterium-, konstruk- en voorspellingsgeldigheid van die LOV gevind.

Die Algemene Selfdoeltreffendheidskaal (ASDV) (Schwarzer, 1993) is gebruik om deelnemers se algemene selfdoeltreffendheid te meet. Die ASDV bestaan uit 10 items. Schwarzer (1993) het alfakoeffisiënte wat varieer van 0,75 tot 0,90 vir die ASDV gevind. 'n Bevestigende faktoranalise het aangedui dat die skaal eendimensioneel was in al die steekproewe. Rothmann en Van Rensburg (2001) se navorsing toon ' $n$ betroubaarheidskoëffisiënt van 0,80 vir ASDV. Die skaal beskik oor konvergente en divergente geldigheid. Schwarzer (1993) het gevind dat die ASDV positief korreleer met selfwaarde en optimisme en dat dit negatief korreleer met angs, depressie en fisieke simptome. Die skaal beskik oor konvergente en divergente geldigheid.

Die Werk-Lokus-van-Beheer-Skaal (WLVB) (Spector, 1988) is gebruik om deelnemers se lokus van beheer in werkskonteks te meet. Die WLVB bestaan uit 16 items. Spector (1988) het Cronbach alfakoëffisiënte van tussen 0,75 en 0,85 vir die WLVB gevind. Rothmann en Van Rensburg (2001) het in hul navorsing 'n alfakoëffisiënt van 0,70 vir die WLVB gevind. In 'n poging om die WLVB te valideer, het Spector (1988) werksveranderlikes wat voorheen met Rotter se skaal gekorreleer is, daarmee in verband gebring. Hy rapporteer dat baie van die korrelasies tussen werk-lokus-van-beheer en organisasieveranderlikes hoër is as dié wat deur Rotter gevind is. Maram en Miller (1998) en Spector (1988) het bevind dat die WLVB oor konstrukgeldigheid beskik.

\section{Statistiese ontledings}

Die statistiese ontledings is met behulp van die SAS-program (SAS Institute, 2000) gedoen. Die beskrywing en vergelyking 
van die resultate geskied aan die hand van rekenkundige gemiddeldes en standaardafwykings. Die Cronbach alfakoëffisiënt van elke meetinstrument is bereken om die interne konsekwentheid van die vraelyste aan te toon. Gemiddelde interitem-korrelasies is vir elke skaal bereken, aangesien Clark en Watson (1995) waarsku dat 'n hoë interne konsekwentheid dikwels ten koste van die geldigheid van 'n skaal kan wees. ' $n$ Gemiddelde interitem-korrelasie wat varieer van 0,15 tot 0,50 per skaal is (afhangend van die breedte van die konstruk wat die skaal meet) aanvaarbaar (Clark \& Watson, 1995). Pearson-korrelasies is gebruik om te bepaal in watter mate die veranderlikes met mekaar verband hou. Die afsnypunt vir praktiese betekenisvolheid van korrelasies is op $r=0,30$ (mediumeffek, Cohen, 1988) gestel. Stapsgewyse meervoudige regressie-ontleding is gebruik om die proporsie van die totale variansie van uitbranding wat deur koherensiesin, selfdoeltreffendheid en lokus van beheer verklaar word, te bepaal. Die effekgrootte in die geval van meervoudige regressie is gegee deur die volgende formule (Steyn, 1999): $f^{2}=R^{2} / 1-R^{2}$. 'n Afsnypunt van $f^{2}=0,35$ (groot effek, Steyn, 1999) is gestel.

\section{RESULTATE}

Die beskrywende statistiek en die interne konsekwentheid van die meetinstrumente van die verskillende psigologiese kragte word vir die totale ondersoekgroep in Tabel 2 weergegee.

TABLEL 2

BESKRYWENDE STATISTIEK EN BETROUBAARHEID VAN MEETINSTRUMENTE

\begin{tabular}{|c|c|c|c|c|c|c|}
\hline ITEM & Rek.Gem. & $s$ & Skeefheid & $\begin{array}{c}\text { Kurtose } \\
\text { Interitem- } \\
\text { korrelasie }\end{array}$ & Gem. & $\alpha$ \\
\hline MBI - Uitputting & 14,75 & 6,58 & $-0,07$ & $-0,08$ & 0,61 & 0,89 \\
\hline MBI - Sinisme & 11,98 & 5,80 & $-0,07$ & $-0,62$ & 0,40 & 0,75 \\
\hline $\begin{array}{l}\text { MBI - Persoonlike } \\
\text { Doeltreffendheid }\end{array}$ & 24,20 & 6,97 & $-0,27$ & $-0,53$ & 0,49 & 0,85 \\
\hline $\begin{array}{l}\text { Lewensoriëntasievraelys } \\
\text { (LOV) }\end{array}$ & 132,39 & 22,66 & $-0,55$ & 0,97 & 0,27 & 0,91 \\
\hline $\begin{array}{l}\text { Algemene Selfdoeltref- } \\
\text { fendheidsvraelys (ASDV) }\end{array}$ & 31,13 & 4,40 & $-0,54$ & 0,84 & 0,42 & 0,88 \\
\hline $\begin{array}{l}\text { Werk-Lokus-van-Beheer- } \\
\text { Vraelys (WLVB) }\end{array}$ & 42,95 & 12,74 & 0,30 & $-0,37$ & 0,31 & 0,89 \\
\hline
\end{tabular}

Wat skeefheid en kurtose betref, blyk dit uit Tabel 2 dat daar slegs 'n geringe afwyking vanaf 0 is, wat aandui dat die tellings redelik normaal versprei is. Tabel 2 toon Cronbach alfakoëffisiënte wat wissel tussen 0,75 en 0,89 vir die MBI-GS. Hierdie alfakoëffisiënte is aanvaarbaar in vergelyking met die afsnypunt van 0,70 soos voorgestel deur Nunnally en Bernstein (1994). Die gemiddelde interitem-korrelasie van die MBI-GS is ook aanvaarbaar $(0,15 \leq r \leq 0,50$; Clark \& Watson, 1995). Soos uit Tabel 2 blyk, is die alfakoëffisiënte van die LOV, ASDV en WLVB almal hoër as die riglyn van 0,70 (Nunnally \& Bernstein, 1994). Die gemiddelde interitem-korrelasies van al drie hierdie vraelyste is ook aanvaarbaar $(0,15 \leq r$ 0,50; Clark \& Watson, 1995).

Die vlakke van uitbranding van maatskaplike werkers volgens die drie skale van die MBI-GS word in Tabel 3 vergelyk met norme wat deur Maslach et al. (1996) gegee word.

Tabel 3 toon aan dat 47,66\% van die deelnemers hoë vlakke van uitputting ervaar. Verder blyk dit dat $62,62 \%$ van die deelnemers 'n hoë mate van sinisme ervaar en $51,40 \%$ lae persoonlike doeltreffendheid ervaar.

TABEL 3

KLASSIFIK ASIE VAN MBI-TELLINGS $(N=107)$

\begin{tabular}{lcc}
\hline VLAK & FREKWENSIE & PERSENTASIE \\
\hline Uitputting & 51 & \\
Hoog & 27 & 47,66 \\
Gemiddeld & 29 & 25,23 \\
Laag & 67 & 27,10 \\
Sinisme & & 62,62 \\
Hoog & 21 & \\
Gemiddeld & 19 & 19,63 \\
Laag & & 17,76 \\
Persoonlike Doeltreffendheid & 27 & \\
Hoog & 25 & 25,23 \\
Gemiddeld & 55 & 23,36 \\
Laag & & 51,40 \\
\hline
\end{tabular}

Die korrelasies tussen die verskillende koherensiesin, selfdoeltreffendheid en lokus van beheer enersyds en uitbranding andersyds word in Tabel 4 weergegee.

TABEL 4

ProduKMOMENT-KORRELASIEKOËFFISIËNTE TUSSEN DIE MBI-GS, LOV, ASDV EN WLVB

\begin{tabular}{lccc}
\hline & LOV & ASDV & WLVB \\
\hline MBI - Uitputting & $-0,50 * *$ & $-0,29$ & $0,32 *$ \\
MBI - Sinisme & $-0,61 * *$ & $-0,42 *$ & $0,48 *$ \\
MBI - Persoonlike Doeltreffendheid & $0,36 *$ & $-0,50 * *$ & $-0,26$ \\
LOV & - & $0,63 * *$ & $0,59 * *$ \\
ASDV & - & - & $-0,45 *$ \\
\hline
\end{tabular}

${ }^{*}$ Korrelasie is prakties betekenisvol $r \geq 0,30$ (mediumeffek)

** Korrelasie is prakties betekenisvol $r \geq 0,50$ (groot effek)

Volgens die resultate in Tabel 4 bestaan daar prakties betekenisvolle verbande met 'n groot effek $(r \geq 0,50)$ ten opsigte van die volgende items: LOV en ASDV, die LOV en Uitputting, die LOV en Sinisme asook die ASDV en Persoonlike Doeltreffendheid. Praktiese betekenisvolle verbande van mediumeffek $(r \geq 0,30)$ is tussen die ASDV en WLVB, LOV en Persoonlike Doeltreffendheid, die ASDV en Sinisme, die WLVB enersyds en Uitputting en Sinisme andersyds gevind.

In Tabel 5 word die regressie-analise met betrekking tot koherensiesin, selfdoeltreffendheid, lokus van beheer en biografiese items enersyds en Uitputting (soos gemeet deur die MBI - GS) andersyds aangetoon.

Tabel 5 dui aan dat $27 \%$ van die variansie ten opsigte van Uitputting (soos gemeet deur die MBI-GS) van maatskaplike werkers voorspel word deur koherensiesin en huwelikstatus. Die meervoudige korrelasie van 0,51 is prakties betekenisvol (groot effek) $\left(f^{2}=0,36\right)$. Dit blyk verder uit Tabel 5 dat koherensiesin en huwelikstatus die beste voorspellers van Uitputting is.

In Tabel 6 word die regressie-analise met betrekking tot koherensiesin, selfdoeltreffendheid, lokus van beheer en biografiese items enersyds en Sinisme (soos gemeet deur die MBI - GS) andersyds aangetoon. 
Uit Tabel 6 blyk dit dat $41 \%$ van die variansie ten opsigte van Sinisme (soos gemeet deur die MBI-GS) voorspel word deur koherensiesin, lokus van beheer en huwelikstatus. Die meervoudige korrelasie van 0,64 is prakties betekenisvol (groot effek) $\left(f^{2}=0,69\right)$. Dit blyk verder uit Tabel 6 dat koherensiesin, lokus van beheer en huwelikstatus die beste voorspellers van sinisme is.

TABEL 5

REGRESSIE-ANALISE TEN OPSIGTE VAN UITPUTTING

\begin{tabular}{lllll}
\hline \multicolumn{2}{l}{ VARIANSIE - ONTLEDING } & & \\
\hline $\boldsymbol{R}=\mathbf{0 , 5 2}$ & $\begin{array}{l}\text { Bron van } \\
\text { variansie }\end{array}$ & $\begin{array}{l}\text { Grade van } \\
\text { vryheid }\end{array}$ & $\begin{array}{l}\text { Som van } \\
\text { kwadrate }\end{array}$ & $\begin{array}{l}\text { Gemiddelde } \\
\text { kwadrate } \\
R^{2}=0,27\end{array}$ \\
Regressie & 2 & 1238,484 & 619,242 \\
& Residu & 104 & 3357,702 & 32,285 \\
& $F=0,607$ & & & \\
& $f^{2}=0,369$ & & & \\
\hline
\end{tabular}

VERANDERLIKES IN DIE VERGELYKING

\begin{tabular}{lcccc}
$\begin{array}{l}\text { Onafhanklike } \\
\text { Veranderlikes }\end{array}$ & B & $\begin{array}{c}\text { Standaardfout } \\
\text { van B }\end{array}$ & $\boldsymbol{F}$ & $\boldsymbol{P}$ \\
Konstante & 31,10 & 3,72 & 69,94 & 0,0001 \\
Koherensiesin & $-0,15$ & 0,02 & 36,08 & 0,0001 \\
Huwelikstatus & 1,64 & 1,00 & 2,70 & 0,1035 \\
\hline
\end{tabular}

* Prakties betekenisvol: $f^{2} \geq 0,35$ (groot effek)

TABEL 6

REGRESSIE-ANALISE TEN OPSIGTE VAN SINISME

\begin{tabular}{|c|c|c|c|c|}
\hline \multicolumn{5}{|c|}{ VARIANSIE - ONTLEDING } \\
\hline$R=0,64$ & $\begin{array}{l}\text { Bron van } \\
\text { variansie }\end{array}$ & $\begin{array}{l}\text { Grade van } \\
\text { vryheid }\end{array}$ & $\begin{array}{l}\text { Som van } \\
\text { kwadrate }\end{array}$ & $\begin{array}{l}\text { Gemiddelde } \\
\text { kwadrate }\end{array}$ \\
\hline \multirow[t]{4}{*}{$R^{2}=0,41$} & Regressie & 3 & 1458,90 & 486,30 \\
\hline & Residu & 103 & 2109,07 & 20,48 \\
\hline & $F=0,83$ & & & \\
\hline & $f^{2}=0,69$ & & & \\
\hline
\end{tabular}

VERANDERLIKES IN DIE VERGELYKING

\begin{tabular}{lrcrc}
$\begin{array}{l}\text { Onafhanklike } \\
\text { Veranderlikes }\end{array}$ & B & $\begin{array}{c}\text { Standaardfout } \\
\text { van B }\end{array}$ & $\boldsymbol{F}$ & $\boldsymbol{P}$ \\
Konstante & 24,30 & 4,64 & 27,44 & 0,0001 \\
Lokus van beheer & 0,07 & 0,04 & 2,66 & 0,1058 \\
Koherensiesin & $-0,13$ & 0,02 & 30,45 & 0,0001 \\
Huwelikstatus & 1,28 & 0,80 & 2,52 & 0,1154 \\
\hline
\end{tabular}

* Prakties betekenisvol: $f^{2} \geq 0,35$ (groot effek)

In Tabel 7 word die regressie-analise met betrekking tot koherensiesin, selfdoeltreffendheid, lokus van beheer en biografiese items enersyds en Persoonlike Doeltreffendheid (soos gemeet deur die MBI - GS) andersyds aangetoon.

Uit Tabel 7 blyk dit dat $30 \%$ van die variansie in totale Persoonlike Doeltreffendheid (soos gemeet deur die MBI-GS) voorspel word deur die ASDV-telling, geslag en werkstatus. Die meervoudige korrelasie van 0,54 is prakties betekenisvol (groot effek) $\left(f^{2}=0,42\right)$. Dit blyk verder uit Tabel 7 dat algemene selfdoeltreffendheid, geslag en werkstatus die beste voorspellers van Persoonlike Doeltreffendheid is.
TABEL 7

REgRESSIE-ANALISE TEN OPSIGTE VAN PERSOONLIKE TREFFENDHEID

\begin{tabular}{lllll}
\hline VARIANSIE - ONTLEDING & & & \\
\hline $\boldsymbol{R}=\mathbf{0 , 5 5}$ & $\begin{array}{l}\text { Bron van } \\
\text { variansie }\end{array}$ & $\begin{array}{l}\text { Grade van } \\
\text { vryheid }\end{array}$ & $\begin{array}{l}\text { Som van } \\
\text { kwadrate }\end{array}$ & $\begin{array}{l}\text { Gemiddelde } \\
\text { kwadrate }\end{array}$ \\
$R^{2}=0,30$ & Regressie & 3 & 1543,709 & 514,569 \\
& Residu & 103 & 3607,767 & 35,026 \\
& $F=0,65$ & & & \\
& $f^{2}=0,43$ & & & \\
\end{tabular}

VERANDERLIKES IN DIE VERGELYKING

$\begin{array}{lrcrr}\begin{array}{l}\text { Onafhanklike } \\ \text { Veranderlikes }\end{array} & \text { B } & \begin{array}{c}\text { Standaardfout } \\ \text { van B }\end{array} & \boldsymbol{F} & \boldsymbol{P} \\ \text { Konstante } & 16,36 & 8,02 & 4,17 & 0,0438 \\ \text { ASDV } & 0,80 & 0,13 & 35,79 & 0,001 \\ \text { Geslag } & -6,65 & 3,08 & 4,65 & 0,0335 \\ \text { Werkstatus } & -3,33 & 1,61 & 4,29 & 0,0408\end{array}$

* Prakties betekenisvol: $f^{2} \geq 0,35$ (groot effek)

\section{BESPREKING}

Die resultate wat in die empiriese ondersoek verkry is, dui daarop dat die ondersoekgroep hoë vlakke van uitbranding ervaar. Die maatskaplike werkers in hierdie ondersoek openbaar relatief hoë vlakke van uitputting en sinisme. Die hoë vlakke van uitputting beteken ' $n$ afname in emosionele hulpbronne van 'n individu, wat impliseer dat die individu emosioneel gedreineer en fisiek uitgeput voel. Die hoë vlakke van sinisme dui op 'n negatiewe, kliniese en onsensitiewe houding teenoor kollegas en kliënte. Die ondersoekgroep ervaar lae tot gemiddelde vlakke van persoonlike doeltreffendheid. In die algemeen meen hulle dat hulle nie altyd oor die vermoë beskik om die kliënt se behoeftes aan te pak nie en is bloot soms tevrede dat hulle die basiese elemente van hulle werk bevredigend verrig. Die laer vlakke van persoonlike doeltreffendheid by die maatskaplike werkers kan verduidelik word in terme van min erkenning vir die werk wat gedoen word, en 'n kroniese energietekort waar die energie vanaf die maatskaplike werker na die kliënt vloei sonder enige energieterugvloei en die komplekse aard van die werk van maatskaplike werkers (vgl. Schaufeli \& Enzmann, 1998).

Dit blyk uit die resultate dat die ondersoekgroep se koherensiesin ondergemiddeld was in vergelyking met ander voorbeelde wat deur Rothmann (2000) geanaliseer is. 'n Sterk koherensiesin word deur lewenservaringe bevorder wat die gevolg van algemene weerstandshulpbronne is (Antonovsky, 1987a). Die resultate van die ondersoek toon aan dat uitbranding (uitputting, sinisme en lae persoonlike doeltreffendheid) negatief verwant is aan koherensiesin. Faktore wat verder ' $n$ negatiewe uitwerking op die maatskaplike werker se koherensiesin het, is hoë kliëntelading, swak prognose by kliënte wat frustrasies meebring en die feit dat die maatskaplike werker nie 'n keuse het wie hulle moet help nie. Verder is dit moeilik om maatskaplike funksionering te meet, wat vir 'n lae belewing van effektiwiteit sorg. Die ervaring van sukses lê daarin dat die individu glo dat hy of sy oor die vermoë beskik om die maatskaplike omgewing waarin hy of sy werk, te kan beinvloed (Harrison, 1983). Indien daar geen sukses is nie, het die maatskaplike werker niks om sy of haar professionele selfbeeld te bou nie. Die gebrek aan voldoende hulpbronne is ook 'n stremmende faktor in maatskaplike werk (Harrison, 1983). 'n Tekort aan fondse, behuising en werkgeleenthede is wesenlike probleme wat die magteloosheid van maatskaplike werkers vergroot.

Die resultate van hierdie ondersoek ondersteun vorige bevindinge: 'n persoon met 'n sterk koherensiesin sal minder gevoelens van uitbranding ervaar (Rothmann, Malan \& Rothmann, 2001). Hoe sterker die koherensiesin, hoe groter is 
die tenders om die stressor te identifiseer waarmee 'n persoon gekonfronteer word en die regte hulpbron vir die spesifieke situasie te kies. Die maatskaplike werker wat die stimuli van die omgewing nie as georden en gestruktureer waarneem nie, wat gebeure in hulle lewe as onhanteerbaar ervaar en voel dat eise nie sin maak nie, ervaar ' $n$ afname in emosionele hulpbronne en voel emosioneel gedreineer. Hierdie resultate bevestig Gilbar (1998) se bevindinge met maatskaplike werkers, Levert, Lucas en Ortlepp (2000) se bevindinge met psigiatriese verpleegsters en Basson en Rothmann (2002) se bevindinge met aptekers. 'n Persoon wat 'n sterk koherensiesin het, beskik oor die vermoë om 'n stresvolle situasie te verstaan en het ook die persepsie dat hy of sy dit kan hanteer en sin daaruit kan maak (Antonovsky, 1987b). Dit wil voorkom asof die maatskaplike werkers met ' $n$ sterk koherensiesin, minder geneig is om uitbranding te ervaar, waarskynlik vanweë die persepsie van beheer oor die situasie en die vermoë om potensiële hulpbronne te benut in 'n poging om die eise van chroniese werkstres te hanteer en sin daarin te vind. Hierdie bevindinge word deur vorige navorsing ondersteun (Compas, Banez, Malcorne \& Worsham, 1991; Feldt, 1997; Gilbar, 1998; Strümpfer, 1990).

Antonovsky (1979) toon aan dat hoe groter die stresvrag is, hoe belangriker is die rol van goedaardige of salutogene faktore wat coping-moontlikhede in mense sal ontsluit. Hy stel in hierdie verband die konsep algemene weerstandshulpbronne bekend. Dit verwys na alle reserwes - geld, egokrag, kulturele stabiliteit, sosiale ondersteuning en so meer - of enige ander faktore wat bydra tot die bied van weerstand teen stressors en tot die opbou en versterking van suksesvolle streshanteringsvermoëns (Antonovsky, 1987a).

Die resultate van die ondersoek het aangetoon dat koherensiesin sterk verband hou met selfdoeltreffendheid en lokus van beheer. Dit blyk dus dat persone wat oor 'n sterk koherensiesin beskik, ook 'n hoë vlak van selfdoeltreffendheid ervaar en oor interne lokus van beheer beskik. Dit blyk verder dat uitbranding positief verwant is aan 'n swak koherensiesin, 'n lae algemene selfdoeltreffendheid en eksterne lokus van beheer. Hierdie bevinding kan ook beskou word in die lig van Hobfoll (2001) se siening van hulpbronkaravane ("resource caravans"), waar een hulpbron tipies verbind is met ander hulpbronne wat 'n persoon het en soortgelyk met die afwesigheid daarvan.

Volgens Hobfoll (2001) is uitbranding die gevolg wanneer individue misluk om genoegsame hulpbronne te bekom. Daarom kan daar twee interpretasies van die verwantskap tussen 'n swak koherensiesin en uitbranding gemaak word. Eerstens is individue met beter en meer hulpbronne minder kwesbaar ten opsigte van hulpbronverlies en meer in staat tot hulpbroninwinning. Omgekeerd, dié met minder hulpbronne is meer kwesbaar vir hulpbronverlies en minder in staat om hulpbronne te bekom. Koherensiesin word beskou as 'n "breë band". hulpbron, terwyl uitbranding die resultaat van 'n tekort aan hulpbronne kan wees. Tweedens is dit moontlik dat die koherensiesin van maatskaplike werkers verminder as gevolg van uitbranding. Aangesien data ten opsigte van koherensiesin en uitbranding gelyktydig in hierdie studie ingesamel is, kan die rigting van die verbande nie bepaal word nie - dit sou longitudinale data vereis. Omdat koherensiesin reeds vroeg in 'n individu se lewe ontwikkel en uitbranding slegs na 'n aantal werksjare ontstaan (as dit wel voorkom), kan geredeneer word dat ' $n$ sterk koherensiesin ' $n$ individu teen uitbranding beskerm (Strümpfer, 2002).

Die resultate toon verder dat die ondersoekgroep se algemene selfdoeltreffendheid ook negatief verwant was aan sinisme as komponent van uitbranding en positief verwant is aan persoonlike doeltreffendheid. 'n Hoë mate van selfdoeltreffendheid help om 'n gevoel van kalmte te ontwikkel wanneer 'n moeilike taak aangepak en afgehandel moet word. In teenstelling hiermee sal die maatskaplike werker wat 'n lae mate van selfdoeltreffendheid het, glo dat die taak, lewenseise of stressors wat gehanteer moet word, bo sy of haar vuurmaakplek is. Die gevolg is dat stres en depressie ontstaan, en die maatskaplike werker het geen visie oor hoe om die potensiële probleem op te los nie (Pajares, 2000). Hierdie voortdurende ervaring van stres en depressie lei tot uitputting en sinisme.

Dit blyk verder dat eksterne lokus van beheer positief verwant is aan uitputting en sinisme en negatief verwant aan persoonlike doeltreffendheid. Maatskaplike werkers wat glo dat hulle gebeure in hul lewens kan beheer, beskik oor 'n interne lokus van beheer, en maatskaplike werkers wat glo dat die omgewing en noodlot gebeure beheer, beskik oor 'n eksterne lokus van beheer. Dit sluit aan by Burns (1988) wat noem dat lokus van beheer nog 'n persoonlikheidseienskap is wat in individu se ervaring van uitbranding beïnvloed. Burns (1988) noem dat persone met 'n eksterne lokus van beheer voel dat hulle nie beheer het oor hulle omgewing nie en is gevolglik meer vatbaar vir uitbranding.

Dit blyk verder dat koherensiesin 'n goeie voorspeller van uitputting is. Die regressievergelyking vir uitputting (as komponent van uitbranding) kan soos volg geskryf word: Uitputting $=31,10-0,15$ (Koherensiesin) $+1,64$ (Huwelikstatus). Die veranderlikes voorspel $27 \%$ van die variansie in uitputting.

Koherensiesin en lokus van beheer is ook goeie voorspellers van sinisme. Die regressievergelyking vir sinisme (as komponent van uitbranding) kan soos volg geskryf word: Sinisme $=24,30+0,07$ (Lokus van Beheer) $-0,13$ (Koherensiesin) $+1,28$ (Huwelikstatus). Die veranderlikes voorspel $41 \%$ van die variansie in sinisme.

Algemene selfdoeltreffendheid is ' $n$ goeie voorspeller van persoonlike doeltreffendheid. Die regressievergelyking vir persoonlike doeltreffendheid (as komponent van uitbranding) kan soos volg geskryf word: Persoonlike Doeltreffendheid = $16,36+0,80$ (ASDV) - 6,65 (Geslag) - 3,33 (Werkstatus). Die veranderlikes voorspel $30 \%$ van die variansie in persoonlike doeltreffendheid.

Verskeie beperkings het in die empiriese ondersoek voorgekom. Daar is van 'n beskikbaarheidsteekproef en nie van 'n ewekansige steekproef gebruik gemaak nie. Die ondersoekgroep het baie min mans en ander kultuurgroepe as blankes ingesluit. As gevolg van die aard van die navorsingsontwerp kan die rigting van verkreë verbande nie bepaal word nie. Interaksie tussen die disposisionele faktore en situasionele faktore wat uitbranding kan veroorsaak, is nie bepaal nie.

\section{AANBEVELINGS}

Organisasies wat maatskaplike werkers in diens neem, kan bydra tot die ontwikkeling van hul koherensiesin deur inligting konstant, gestruktureerd, georden en in verstaanbare formaat aan te bied. Maatskaplike werkers moet verder in staat gestel word om hulle rolle binne die groter geheel te kan identifiseer wat die verstaanbaarheidskomponent van koherensiesin sal verhoog. Deur maatskaplike werkers toe te rus met die nodige kennis, vaardighede, materiaal, instrumente en ander hulpbronne, asook te verseker dat daar 'n balans in die uitvoering van take bestaan, sal hulle toenemend voel dat die werkseise hanteerbaar en binne hul, of belangrike ander, se vermoë val. Deelname in besluitneming sal maatskaplike werkers se gevoelens van eienaarskap verhoog en tot die betekenisvolheidskomponent van koherensiesin bydra.

Selfdoeltreffendheid kan verhoog word wanneer maatskaplike werkers verseker word van hul organisasies se ondersteuning en hulle die nodige vaardighede aanleer en roluitklaring in so 'n mate afhandel dat dit tot effektiewe diens sal lei. Organisasies moet poog om werk so saam te stel en te struktureer dat dit suksesvolle pogings aanwakker waarin individue hul vaardighede en vermoëns kan toepas en uitleef. 'n Interne lokus van beheer 
kan gestimuleer word deur meer verantwoordelikhede op te lê, take en werk volgens meriete te beoordeel en sodoende insette en inisiatief van maatskaplike werkers te eis.

Organisasies kan maatskaplike werkers in diens neem wat oor 'n sterk koherensiesin, hoë selfdoeltreffendheid en interne lokus van beheer beskik en dit deel van hul keuringsproses maak om sodoende uitbranding by maatskaplike werkers te voorkom. Meer navorsing in 'n keuringskonteks is egter nodig alvorens die genoemde konstrukte in 'n keuringsbattery ingesluit word.

Toekomstige navorsing behoort te fokus op die verband tussen koherensiesin, selfdoeltreffendheid, lokus van beheer en uitbranding in ander kontekste en met groter steekproewe nagevors word. Koherensiesin, selfdoeltreffendheid en lokus van beheer moet ook met betrekking tot ander veranderlikes soos werksprestasie en werkstevredenheid by maatskaplike werkers nagevors word. Die mate waarin die gebruik van verskillende coping-strategieë, maatskaplike werkers se uitbrandingsvlakke voorspel, kan ondersoek word. Situasionele oorsake van uitbranding moet in toekomstige studies nagevors word.

\section{VERWYSINGS}

Antonovsky, A. (1979). Health, stress and coping: New perspective on mental and physical well being. San Francisco: Jossey-Bass.

Antonovsky, A. (1987a). Unraveling the mystery of health: How people manage stress and stay well. San Francisco: Jossey-Bass.

Antonovsky, A. (1987b). Health promoting factors at work: The sense of coherence. In R. Kalimo, M. Eltatawi, \& C. Cooper (Eds.), Psychosocial factors at work and their effects on health. (pp. 53-167). World Health Organization, Geneva.

Antonovsky, A. (1991). The structural sources of salutogenic strengths. In C.L. Cooper \& R. Payne (Eds.), Personality and stress: Individual differences in the stress process. New York: Wiley.

Antonovsky, A. (1993). The structure and properties of the Sense of Coherence Scale. Social Science and Medicine, 36, 725-733.

Bandura, A. (1997). Self-efficacy: The exercise of control. New York: W.H. Freeman and Company.

Bandura, A. \& Wood, R.E. (1989). Effect of perceived controllability and performance standards on self-regulation of complex decision making. Journal of Personality and Social Psychology, 56, 805-814.

Basson, M.J. \& Rothmann, S. (2002). Sense of coherence, coping and burnout of pharmacists. South African Journal of Economic and Management Sciences, 5 (1), 35-62.

Bowman, B.J. (1996). Cross-cultural validation of Antonovsky's Sense of Coherence Scale. Journal of Clinical Psychology, 52, 547-549.

Burns, R.B. (1988). Coping with stress. Cape Town: Longman.

Cherniss, C. (1980). Professional burnout in the human service organizations. New York: Praeger.

Clark, L.A. \& Watson, D. (1995). Constructing validity: Basic issues in objective scale development, Psychological Assessment, 7, 309-319.

Cohen, J. (1988). Statistical power analysis for the behavioral sciences ( $2^{\text {nd }}$ ed.). Orlando, FL: Academic Press.

Compas, B.E., Banez, G.A., Malcorne, V. \& Worsham, N. (1991). Perceived control and coping with stress: A developmental perspective. Journal of Social Issues, 47 (4), 23-34.

Daniels, K. \& Guppy, A. (1994). Occupational stress, social support, job control, and psychological well-being. Human Relations, 47, 1523-1544.

Feldt, T. (1997). The role of sense of coherence in well-being at work: Analysis of main and moderator effects. Work and Stress, 11, 134-147.

Freudenberger, H.J. (1974). Staff burnout. Journal of Social Issues, 30, 159-165.

Freudenberger, H.J. (1977). Burnout: Occupational hazard of the child care worker. Child Care Quarterly, 6 (2), 60-99.
Freudenberger, H.J. (1980). Burnout: The high cost of achievement. New York: Anchor Press.

Garden, A. (1989). Burnout: The effect of psychological type on research findings. Journal of Occupational Psychology, 62, 223234.

Gilbar, O. (1998). Relationship between burnout and sense of coherence in health social workers. Journal of Social Work in Health Care, 26 (3), 39-49.

Gist, M.E. (1987). Self-efficacy: Implications for organizational behavior and human resource management. Academy of Management Review, 12, 472-485.

Harrison, W.D. (1983). A social competence model of burnout. In B.A. Farber (Ed.), Stress and burnout in the human service professions. New York: Pergamon Press.

Hobfoll, S.E. (2001). The influence of culture, community and the nested-self in the stress process: Advancing conservation of resources theory. Applied Psychology: An International Review, 50, 337-369.

House, R.J., Shane, S.A. \& Herold, D.M. (1996). Rumors of the death of dispositional research are vastly exaggerated. Academy of Management Review, 21, 203-224.

Huysamen, G.K. (1993). Metodologie vir die sosiale en gedragswetenskappe. Halfweghuis: International Thompson Publishing.

Jayaratne, S., Vinokur-Kaplan, D. \& Chess, W.A. (1995). The importance of personal control: A comparison of social workers in private practice and public agency settings. Journal of Applied Social Sciences, 19, 47-59.

Jones, C. \& Page, S. (1986, July). Locus of control, assertiveness, and anxiety as personality variables in stress-related headaches. Headache, 369-374.

Judge, T.A., Locke, E.A. \& Durham, C.C. (1997). The dispositional causes of job satisfaction: A core evaluations approach. Research in Organizational Behavior, 19, 151-188.

Judge, T.A., Locke, E.A., Durham, C.C. \& Kluger, A.N. (1998). Dispositional effects on job and life satisfaction: The role of core evaluations. Journal of Applied Psychology, 83, 17-34.

Kalimo, R. \& Vuori, J. (1990). Work and sense of coherence resources for competence and life satisfaction. Behavioral Medicine, 16 (2), 76-89.

Lahoz, M.R. \& Mason, H.L. (1989). Maslach Burnout Inventory: Factor structures and norms for USA pharmacists. Psychological Reports, 64, 1059-1063.

Lefcourt, H.M. (1982). Locus of control: Current trends in theory and research (2nd ed.). Hillsdale, NJ: Lawrence Erlbaum.

Levert, T., Lucas, M. \& Ortlepp, K. (2000). Burnout in psychiatric nurses: Contributions of the work environment and a sense of coherence. South African Journal of Psychology, 30, 36-43.

Maram, A. \& Miller, K. (1998). An empirical assessment of the construct "work locus of control". Journal of Industrial Psychology, 24 (3), 48-51.

Maslach, C. (1976). Burned-out. Human Behavior, 5, 16-22.

Maslach, C. (1982a). Burnout: The cost of caring. Englewood Cliffs, NJ: Prentice-Hall.

Maslach, C. (1982b). Understanding burnout: Definitional issues in analyzing a complex phenomenon. In W.S. Paine (Ed.), Job stress and burnout: Research, theory and intervention. Beverly Hills, CA: Sage.

Maslach, C. \& Jackson, S.E. (1981a). The measurement of experienced burnout. Journal of Occupational Behavior, 2, 99113.

Maslach, C. \& Jackson, S.E. (1981b). Maslach Burnout Inventory manual: Research edition. Berkeley, CA: Consulting Psychologists Press.

Maslach, C. \& Jackson, S.E. (1984b). Patterns of burnout among a national sample of public contact workers. Journal of Health and Human Resources Administration, 7, 184-212.

Maslach, C. \& Jackson, S.E. (1985). The role of sex and family variables in burnout. Sex Roles, 12, 837-851.

Maslach, C. \& Jackson, S.E. (1986). Maslach Burnout Inventory manual (2 ${ }^{\text {nd }}$ ed.). Palo Alto, CA: Consulting Psychologists Press. 
Maslach, C. \& Jackson, S.E. (1996). Maslach Burnout Inventory Human Services Survey (MBI-HSS). In C. Maslach, S.E. Jackson \& M.P. Leiter, (Eds.), MBI Manual (3 ${ }^{\text {rd }}$ ed.). Palo Alto, CA: Consulting Psychologists Press.

Maslach, C., Jackson, S.E. \& Leiter, M.P. (1996). Maslach Burnout Inventory Manual (3 ${ }^{\text {rd }}$ ed.). Palo Alto, CA: Consulting Psychologists Press.

Meier, S.T. (1983, October). Toward a theory of burnout. Human Relations, 36, 899-910.

Naude, J.L.P. \& Rothmann, S. (2000). Psychological strengths as predictors of job satisfaction of representatives in the fertiliser industry. Management Dynamics, 9 (4), 57-81.

Nunnally, J.C. \& Bernstein, I.H. (1994). Psychometric theory (3 ${ }^{\text {rd }}$ ed.). New York: McGraw-Hill.

Pajares, F. (2000). Current directions in self-efficacy research. Taken from the world wide web, http://www.effchapt.htm

Pines, A.M., Aronson, E. \& Kafry, D. (1981). Burnout: From tedium to personal growth. New York: Free Press.

Pretorius, M. \& Rothmann, S. (2001). Die verband tussen koherensiesin, lokus van beheer, selfdoeltreffendheid en werkstevredenheid. Tydskrif vir Bedryfsielkunde, 27 (1), 25-31.

Rahim, A. (1996). Stress, strain, and their moderators: An empirical comparison of entrepreneurs and managers. Journal of Small Business Management. Jan.

Reber, A.S. (1995). Dictionary of psychology. London: Penguin Books.

Ross, E. \& Fridjhon, P. (1995). Burnout: A smoldering problem among South African social workers. Social Work, 31, 265279.

Rothmann, S. (2000, July). Sense of coherence, locus of control and job satisfaction. Paper presented at the $27^{\text {th }}$ International Congress of Psychology, Stockholm, Sweden.

Rothmann, S., Malan, A.M. \& Rothmann, J.C. (2001, August). Sense of coherence, coping and burnout in a corporate pharmacy group. Paper presented at the $7^{\text {th }}$ Annual PsySSA Conference, Johannesburg, RSA.

Rothmann, S. \& Van Rensburg, P. (2001, May). Suicide ideation in the South African Police Services. Paper presented at the $10^{\text {th }}$ European Congress on Work and Organizational Psychology, Prague, Czech Republic.

Rotter, J.B. (1966). Generalized expectancies for internal versus external control of reinforcement. Psychological Monographs, 80: $1-28$.

Rotter, J.B., Chance, J.E. \& Phares, E.J. (1972). Application of a social learning theory of personality. New York: Holt Rinehart $\&$ Winston.
Rumbaut, R.G., Anderson, J.P. \& Kaplan, R.M. (1983). Stress, Health, and the Sense of Coherence. In M.J. Magenheim (Ed.), Geriatric Medicine and the Social Sciences (pp. 82-86). Philadelphia: Saunders.

Ryan, R.M. \& Deci, E.L. (2000). Self-determination theory and the facilitation of intrinsic motivation, social development, and well-being. American Psychologist, 55, 68-78.

SAS Institute. (2000). The SAS System for Windows: Release 8.01. Cary, NC: SAS Institute Inc.

Schaubroeck, J. \& Merrit, D.E. (1997). Divergent effects of job control on coping with work stressors: The key role of selfefficacy. Academy of Management Journal, 40, 738-755.

Schaufeli, W.B. \& Enzmann, D. (1998). The burnout companion to study and practice: A critical analysis. London: Taylor \& Francis.

Schwarzer, R. (1993). Measurement of perceived self-efficacy. Psychometric scales for cross-cultural research. Berlin, Germany: Freie Universität Berlin.

Seeman, M. \& Seeman, T.E. (1983). Health behavior and personal autonomy: A longitudinal study of the sense of control in illness. Journal of Health and Social Behavior, 24, 144-160.

Seligman, M.E.P. \& Csikszentmihalyi, M. (2000). Positive psychology: An introduction. American Psychologist, 55, 5-14.

Sherer, M. \& Maddux, J.E. (1982). The Self-efficacy Scale: Construction and validation. Psychological Reports, 51, 663671.

Spector, P.E. (1988). Development of the Work Locus of Control Scale. Journal of Occupational Psychology, 61, 335-340.

Steyn, H.S. (1999). Praktiese betekenisvolheid: Die gebruik van effekgroottes. Wetenskaplike bydraes - Reeks B: Natuurwetenskappe Nr. 117. Potchefstroom: PU vir CHO.

Strümpfer, D.J.W. (1990). Salutogenesis: A new paradigm. South African Journal of Psychology, 20, 265-276.

Strümpfer, D.J.W. (1995). The origins of health and strength: From salutogenesis to fortigenesis. South African Journal of Psychology, 25, 81- 89.

Strümpfer, D.J.W. (2002, March). Resiling: A stitch that saves nine. Paper presented presented at the $1^{\text {st }}$ South African Burnout Conference, Potchefstroom.

Tubbs, W. (1994). The roots of stress-death and juvenile delinquency in Japan: Disciplinary ambivalence and perceived locus of control. The Academy of Management Executive, 8, 68-76.

Venter, M. (1989). Werkspanning onder 'n groep bestuurders: 'n Empiriese ondersoek. Ongepubliseerde meestergraadskripsie, $\mathrm{PU}$ vir $\mathrm{CHO}$, Potchefstroom.

Wissing, M.P., de Waal, M. \& de Beer, I. (1992, July). Sense of coherence and stress symptomatology. Paper presented at $25^{\text {th }}$ International Congress of Psychology, Brussels, Belgium. 